(c) American Dairy Science Association, 2005.

\title{
Lactational Response of Cows Fed Condensed Corn Distillers Solubles*
}

\author{
C. R. Da Cruz,† M. J. Brouk, $\ddagger$ and D. J. Schingoethe \\ Dairy Science Department, South Dakota State University, Brookings 57007-0647
}

\begin{abstract}
Fifteen Holstein cows ( 6 multiparous and 9 primiparous) in early lactation were used in a replicated $3 \times 3$ Latin square design with 5 -wk periods to evaluate the use of condensed corn distillers solubles (CCDS) in the total mixed ration. Diets were control (0\%), low (5\%), or high (10\% of dry matter) CCDS. All diets contained alfalfa hay, corn silage, rolled corn, and a concentrate supplement formulated to yield isonitrogenous diets. Condensed corn distillers solubles replaced a portion of the rolled corn and soybean meal in the control diet. Data were collected from wk 3 to 5 of each 5 -wk period. Dry matter intakes $(23.4,24.4$, and $22.5 \mathrm{~kg} / \mathrm{d}$ for control, low, and high CCDS, respectively) were similar for CCDS and control and tended to be greater for low than for high CCDS. Milk yields (34.1, 35.5, and $35.8 \mathrm{~kg} /$ d) were greater for added CCDS vs. control, with no additional benefit found by feeding a high over a low amount of CCDS. Milk fat percentage decreased slightly, whereas protein and lactose production increased when cows were fed CCDS. Medium-chain fatty acids in milk fat were decreased and long-chain fatty acids increased by feeding CCDS, and similar changes were found comparing high with low level of CCDS. Unsaturated fatty acids in milk fat tended to be higher for diets containing CCDS compared with control and were higher for high compared with low inclusion. Ruminal ammonia and serum urea nitrogen concentrations were lower when cows were fed CCDS. This study indicated that it is advantageous to feed CCDS at 5\% of dry matter; however, some beneficial changes in milk fatty acid composition were achieved by doubling that amount.
\end{abstract}

(Key words: corn distillers solubles, fat, lactation)

Received April 15, 2005

Accepted June 23, 2005.

Corresponding author: D. J. Schingoethe, e-mail: david. schingoethe@sdstate.edu.

*Published with the approval of the director of the South Dakota Agricultural Experiment Station as Publication Number 3489 of the Journal Series.

$\dagger$ Present address: Rua Sao Pedro, 2264, Chapaco, SC 89803901, Brazil.

$\ddagger$ Present address: Department of Animal Sciences and Industry, Kansas State University, Manhattan, KS 66506-1600.
Abbreviation key: CCDS = condensed corn distillers solubles.

\section{INTRODUCTION}

The ethanol industry has grown enormously in the last 10 to 15 yr. Production of ethanol yields some coproducts that constitute important contributions to the economic viability of the industry. A problem with these coproducts, however, is the cost of energy required for drying, a vital step to reach the market under many situations. The use of wet coproducts as feedstuffs has been proposed as a way of circumventing drying costs.

There has been limited research conducted that evaluated the feeding of distillers solubles separately from distillers grains (Schingoethe, 2004); however, condensed corn distillers solubles (CCDS) contains a significant amount of protein and fat and is a potentially important source of such nutrients (Rust et al., 1990; Larson et al., 1993; Schingoethe, 2004). Rust et al. (1990), and a few other cattle feeders' day reports cited by them, demonstrated that feeding CCDS to steers could be advantageous; however, very few studies have been conducted evaluating the use of CCDS in diets of dairy cows. Milk production was increased slightly when cows were fed condensed distillers solubles processed from a mash blend of 60 to $70 \%$ corn, 16 to $18 \%$ rye, and 12 to $14 \%$ barley (Udedibie and Chase, 1988) that contained more protein and less fat than the CCDS used in our study. A study in Finland (Huhtanen and Miettinen, 1992) used wet distillers solubles that likewise contained more protein but less fat than solubles routinely available in the United States and also observed slightly increased milk production. Distillers solubles are usually blended with distillers grains to make distillers grains with solubles, which is marketed as wet or dried distillers grains with solubles. This product is widely used as a feed for dairy and beef cattle (Schingoethe, 2004). If all of the solubles are blended with distillers grains, the solubles account for about 40 to $50 \%$ of the DM in distillers grains with solubles. This study was designed to provide information on the use of CCDS as a feedstuff for lactating cows, focusing on quantifying milk production and composition, total DMI, and ruminal fermentation. 
Table 1. Composition of control, low condensed corn distillers solubles (CCDS), and high CCDS diets.

\begin{tabular}{|c|c|c|c|}
\hline \multirow[b]{2}{*}{ Ingredient } & \multicolumn{3}{|c|}{ Diet } \\
\hline & Control & Low & High \\
\hline & & $\operatorname{diet} \mathrm{DM}$ & - \\
\hline Alfalfa hay, chopped & 24.64 & 24.58 & 24.62 \\
\hline Corn silage & 22.27 & 22.26 & 22.27 \\
\hline Corn, rolled & 28.94 & 25.21 & 21.18 \\
\hline CCDS & - & 5.06 & 10.24 \\
\hline Soybean meal, $44 \% \mathrm{CP}$ & 14.24 & 13.07 & 11.92 \\
\hline Distillers dried grains & 6.63 & 6.57 & 6.53 \\
\hline Limestone, feed grade & 0.91 & 0.90 & 0.90 \\
\hline Dicalcium phosphate & 0.71 & 0.70 & 0.70 \\
\hline Sodium bicarbonate & 0.93 & 0.92 & 0.92 \\
\hline Magnesium oxide & 0.15 & 0.15 & 0.15 \\
\hline Selenium 600 premix $^{1}$ & 0.04 & 0.04 & 0.04 \\
\hline Trace-mineralized salt ${ }^{2}$ & 0.28 & 0.28 & 0.28 \\
\hline Vitamin E premix ${ }^{3}$ & 0.09 & 0.09 & 0.09 \\
\hline Vitamin ADE premix ${ }^{4}$ & 0.17 & 0.17 & 0.17 \\
\hline
\end{tabular}

${ }^{1}$ Contained Ca $38 \%$ and Se 600 ppm.

${ }^{2}$ Contained C1 58.2\%, Na 38.8\%, Mg 0.05\%, Zn 10,000 ppm, Mn 7500 ppm, Fe 6000 ppm, Cu 320 ppm.

${ }^{3}$ Contained 44,000 IU of vitamin E/kg.

${ }^{4}$ Contained 4,400,000 IU of vitamin A, 880,000 IU of vitamin D, and a net $400 \mathrm{IU}$ of vitamin $\mathrm{E} / \mathrm{kg}$.

\section{MATERIALS AND METHODS}

\section{Experimental Plan}

All procedures of this study were conducted under approval of the South Dakota State University Institutional Animal Care and Use Committee. Fifteen early lactation Holstein cows (9 primiparous and 6 multiparous), averaging $25 \mathrm{~d}(\mathrm{SD}=17)$ postpartum at the start of the experiment, were used in a replicated $3 \times 3$ Latin square design to evaluate the effect of the inclusion of 2 levels of CCDS in diets. Cows were assigned to one of the squares according to parity, calving date, and milk production. Experimental periods were 5 wk each, with the initial 2 wk for adaptation and wk 3 through wk 5 for data collection in each of the 3 periods.

Cows were housed in a free-stall facility and fed a TMR once daily for ad libitum consumption using Calan feeding doors (American Calan, Inc., Northwood, NH). Amounts fed and refused were recorded daily throughout the experiment. Water was available at all times. Cows were milked twice daily at 0500 and $1600 \mathrm{~h}$, and milk yield was recorded at each milking. Animals were weighed and body condition scored (Wildman et al., 1982) for 3 consecutive days at the start and end of each period.

Amounts of CCDS in the diets were: $0 \%$ (control), $5 \%$ (low CCDS), or 10\% (high CCDS) of total diet DM (Table 1). Condensed corn distillers solubles substituted for a portion of rolled corn and soybean meal. Diets were formulated to meet nutrient requirements (NRC, 1989) and to be isonitrogenous at levels exceeding recommendations.

Condensed corn distillers solubles were transported and stored in tanks of approximately $1100 \mathrm{~kg}$ capacity. Shipments were received every 4 to 5 wk. Mold growth was successfully prevented by adding $0.08 \%$ of sorbic acid to the CCDS. Condensed corn distillers solubles were mixed daily by mixing in the tank 5 min before incorporating into the TMR. Sixteen samples of the coproduct were obtained directly from the supplier (Heartland Grain Fuels, L.P., Aberdeen, SD) for comparison with compositions of the CCDS being fed (Table 2) to evaluate potential variation in composition of the CCDS.

\section{Sample Collection and Analytical Procedures}

Samples of corn silage, alfalfa hay, rolled corn, and each concentrate supplement (the remainder of the other TMR ingredients) were collected weekly and dried at $55^{\circ} \mathrm{C}$ for $48 \mathrm{~h}$ in a forced air oven. These data were used to adjust proportions of ration ingredients weekly. Samples were then ground through a 2-mm screen of an ultracentrifuge mill (Brinkman Instruments Co., Westbury, NY), stored, and later composited by period. Samples of CCDS were also collected weekly. A 2-mL subsample was dried for $4.5 \mathrm{~h}$ at $105^{\circ} \mathrm{C}$ for DM determination and the remainder stored at $-20^{\circ} \mathrm{C}$ to be composited by period at the end of the trial.

Feed composites, except CCDS, were corrected to $100 \% \mathrm{DM}$ based on subsamples dried at $105^{\circ} \mathrm{C}$ for 16 h. Crude protein, ether extract, and ash content were determined according to the AOAC (1990) procedures. Acid detergent fiber and permanganate lignin were determined as described by Robertson and Van Soest (1981). The techniques reported by Van Soest et al. (1991) were used for NDF determination. Fatty acid composition was determined by GLC of methyl esters (Sukhija and Palmquist, 1988) using a gas chromatograph (model 3700; Varian Aerograph, Walnut Creek, CA).

Dry matter content of composite samples of CCDS was determined as previously described. Crude protein, ash, and fatty acid composition were analyzed by the same procedures used for dry feedstuffs. Fat content was determined using the Röse-Gottlieb method as described by AOAC procedures (1990). Measurements of $\mathrm{pH}$ were done with a Corning ion analyzer 150 (Corning, Inc., Corning, NY).

Milk samples were collected on Monday evenings and Tuesday mornings of wk 3 through 5 of each period. Evening and morning samples were composited in proportion to volumes produced and subdivided into 2 portions. One portion was refrigerated at $4^{\circ} \mathrm{C}$ and sent to 
Table 2. Chemical composition of alfalfa hay (AH), corn silage (CS), rolled corn (RC), condensed corn distillers solubles (CCDS), concentrate supplements, and TMR for control, low CCDS, and high CCDS diets.

\begin{tabular}{|c|c|c|c|c|c|c|c|c|c|c|}
\hline \multirow[b]{2}{*}{ Measurement } & \multirow[b]{2}{*}{$\mathrm{AH}$} & \multirow[b]{2}{*}{ CS } & \multirow[b]{2}{*}{$\mathrm{RC}$} & \multirow[b]{2}{*}{ CCDS } & \multicolumn{3}{|c|}{ Concentrate supplements ${ }^{1}$} & \multicolumn{3}{|c|}{ TMR } \\
\hline & & & & & Control & Low & High & Control & Low & High \\
\hline $\mathrm{DM}, \%$ & 83.4 & 42.8 & 85.1 & 27.4 & 88.2 & 88.1 & 88.6 & 70.0 & 64.3 & 59.4 \\
\hline $\mathrm{CP}$ & 23.5 & 7.8 & 9.5 & 18.1 & 37.9 & 37.9 & 36.9 & 19.4 & 19.5 & 19.4 \\
\hline Ether extract & 2.1 & 2.9 & 3.5 & 21.5 & 4.9 & 5.1 & 5.2 & 3.4 & 4.3 & 5.2 \\
\hline $\mathrm{ADF}$ & 31.4 & 26.4 & 3.5 & 3.1 & 10.6 & 10.2 & 10.3 & 17.2 & 16.8 & 16.6 \\
\hline NDF & 43.1 & 45.0 & 15.4 & 5.2 & 19.4 & 20.4 & 20.3 & 29.7 & 29.2 & 28.8 \\
\hline Lignin & 8.4 & 3.8 & 0.9 & - & 2.4 & 2.7 & 2.5 & 3.8 & 3.8 & 3.7 \\
\hline Ash & 8.9 & 4.1 & 1.4 & 12.5 & 13.3 & 13.5 & 15.1 & 6.7 & 7.2 & 8.0 \\
\hline $\mathrm{pH}$ & - & - & - & 4.3 & - & - & - & - & - & - \\
\hline
\end{tabular}

${ }^{1}$ The other ingredients listed in Table 1 that were included in the TMR.

a laboratory for fat, $\mathrm{CP}$, and lactose determination by midinfrared spectrophotometry (Multispec, Foss Food Technology Corp., Eden Prairie, MN) according to AOAC methods (1990). Somatic cell counts were determined at the same laboratory using a Fossomatic 90 (Multispec, Foss Food Technology Corp.) as described in the AOAC (1990). The other portion of the milk sample was stored at $-20^{\circ} \mathrm{C}$, later thawed at $4^{\circ} \mathrm{C}$, and total fatty acid composition determined by GLC separation of butyl esters as described by Casper et al. (1987).

Samples of rumen fluid were collected via esophageal tube 3 to $4 \mathrm{~h}$ postfeeding once weekly during wk 3, 4 , and 5 of each period. Immediately after collection, samples were stirred, and $\mathrm{pH}$ was measured using an Orion model 701A digital ion analyzer (Orion Research, Cambridge, MA). Sequentially, $20 \mathrm{~mL}$ of rumen fluid was transferred to a tube that had previously received $1.0 \mathrm{~mL}$ of $2 \mathrm{~N} \mathrm{HCl}$ for ruminal ammonia determination (Chaney and Marbach, 1962). To another tube containing $4.0 \mathrm{~mL}$ of $25 \%$ metaphosphoric acid, $20 \mathrm{~mL}$ of rumen fluid was pipetted for VFA analysis (Ottenstein and Bartley, 1971; Casper et al., 1987). The remaining collected rumen fluid was placed on ice, and $\mathrm{pH}$ was determined after 30 to 90 min utilizing a Corning ion analyzer 150 (Corning, Inc.). Because $\mathrm{pH}$ values obtained with the Corning ion analyzer 150 were similar to those obtained at the farm, only $\mathrm{pH}$ values recorded at the farm are reported. Samples were stored at $-20^{\circ} \mathrm{C}$ for later analysis.

Jugular vein blood was sampled at the time of rumen fluid sampling. Blood was drawn into serum separating tubes (Becton Dickinson Vacutainer Systems, Rutherford, NJ), prepared, and stored for urea N determination (Chaney and Marbach, 1962).

\section{Statistical Analyses}

All data were subjected to least squares ANOVA for Latin square designs using the GLM procedure of SAS
(SAS Institute, 1989). Initially, DMI and milk production data were averaged by week. These averages and the rest of the data were used in a Latin square design with week as repeated measures. Because no differences for week were found, data were averaged by period, and differences between treatment means were compared using single degree of freedom orthogonal contrasts. Contrasts were: control vs. added CCDS (low CCDS and high CCDS) and low CCDS vs. high CCDS. Differences were considered to be significant at $P<$ 0.05 , unless otherwise noted.

\section{RESULTS AND DISCUSSION}

\section{Nutrient Content of Diets}

Chemical composition of diet ingredients and TMR are shown in Table 2. The fat content of CCDS was similar to the value reported by Rust et al. (1990), and higher than reported in NRC (1989), whereas CP was less than reported by both sources. The composition of CCDS used in this study was similar to the composition of CCDS sampled at the ethanol plant during the period of the study, and to CCDS that is commonly available from ethanol plants built during the last 10 to $15 \mathrm{yr}$, but considerably higher in fat and lower in CP than the 1989 NRC values. Total mixed rations were isonitrogenous at higher $\mathrm{CP}$ values than intended because of greater than anticipated CP in the alfalfa hay. The variation of ether extract and DM values of the diets were a direct function of adding CCDS.

Fatty acid composition of ration ingredients and TMR are in Table 3. Condensed corn distillers solubles fatty acid profile, with a predominance of C18:2, C18:1, and C16:0, was very similar to the values found for corn oil (Elliott et al., 1993) and for wet corn distillers grains (Schingoethe et al., 1999). Fatty acid composition of other diet ingredients was similar to a previous report (Schingoethe et al., 1999). Total fatty acid contents were 
Table 3. Fatty acid composition of alfalfa hay (AH), corn silage (CS), rolled corn (RC), condensed corn distillers solubles (CCDS), and concentrate supplements, and TMR for control, low CCDS, and high CCDS diets.

\begin{tabular}{|c|c|c|c|c|c|c|c|c|c|c|}
\hline \multirow[b]{2}{*}{ Fatty acid $^{2}$} & \multirow[b]{2}{*}{$\mathrm{AH}$} & \multirow[b]{2}{*}{ CS } & \multirow[b]{2}{*}{$\mathrm{RC}$} & \multirow[b]{2}{*}{ CCDS } & \multicolumn{3}{|c|}{ Concentrate supplements } & \multicolumn{3}{|c|}{$\mathrm{TMR}^{1}$} \\
\hline & & & & & Control & Low & High & Control & Low & High \\
\hline & & & & & (or & DM) & & & & \\
\hline \multirow[t]{2}{*}{ Total } & 1.3 & 2.4 & 4.0 & 16.0 & 4.5 & 4.6 & 4.6 & 3.1 & 3.7 & 4.3 \\
\hline & & & & & \multicolumn{3}{|c|}{ (\% of total fatty acids) } & & & \\
\hline 14:0 & 10.2 & $<0.1$ & $<0.1$ & $<0.1$ & $<0.1$ & $<0.1$ & $<0.1$ & 0.1 & 0.8 & 0.7 \\
\hline $16: 0$ & 28.5 & 15.9 & 14.1 & 13.1 & 14.6 & 14.7 & 14.7 & 16.1 & 15.7 & 15.1 \\
\hline $18: 0$ & 5.2 & 2.2 & 2.1 & 2.6 & 3.3 & 3.3 & 3.3 & 2.9 & 3.0 & 2.8 \\
\hline $18: 1$ & 5.2 & 24.1 & 26.1 & 29.2 & 24.1 & 24.2 & 24.4 & 22.9 & 24.0 & 25.1 \\
\hline $18: 2$ & 20.2 & 53.3 & 54.7 & 52.1 & 52.8 & 52.5 & 52.4 & 50.0 & 50.3 & 50.7 \\
\hline $18: 3$ & 20.5 & 3.3 & 2.6 & 2.3 & 4.8 & 4.8 & 4.8 & 5.2 & 4.9 & 4.4 \\
\hline 20:0 & 0.1 & 1.3 & 8.4 & 0.6 & 0.4 & 0.4 & 0.4 & 0.6 & 0.5 & 0.5 \\
\hline $22: 0$ & 1.9 & $<0.1$ & $<0.1$ & 0.1 & $<0.1$ & $<0.1$ & $<0.1$ & 0.3 & 0.3 & 0.2 \\
\hline $22: 1$ & 5.2 & $<0.1$ & $<3.1$ & $<0.1$ & $<0.1$ & $<0.1$ & $<0.1$ & 0.6 & 0.5 & 0.5 \\
\hline $24: 0$ & 2.5 & $<0.1$ & 3.1 & $<0.1$ & $<0.1$ & $<0.1$ & $<0.1$ & 0.3 & 0.3 & 0.2 \\
\hline
\end{tabular}

${ }^{1}$ Composition calculated on the following percentages (DM basis): Control = AH 24.64, CS 22.27, RC 28.94, concentrate supplements 24.15; Low $=$ AH 24.58, CS 22.26, RC 25.21, CCDS 5.06, concentrate supplements 22.89; High = AH 24.62, CS 22.27, RC 21.18, CCDS 10.24, concentrate supplements 21.69.

${ }^{2}$ Expressed as number of carbons: number of double bonds.

3.1, 3.7, and 4.3\% of DM for the control, low CCDS, and high CCDS TMR, respectively. These numbers are lower than those reported as ether extract in the TMR (Table 2) due to removal of other compounds such as waxes and chlorophyll along with fatty acids during the extraction process. The use of total fatty acids is a more accurate measurement of fat content of feeds (Sukhija and Palmquist, 1988).

\section{Feed Intake}

Dry matter intakes (Table 4) were similar for control and CCDS diets; however, DMI tended $(P=0.08)$ to be less for high vs. low CCDS diets. This tendency was confirmed with lower $\mathrm{CP}, \mathrm{ADF}$, and NDF intakes for high CCDS vs. low $\operatorname{CCDS~}(P=0.07, P=0.06, P=0.03$, respectively; data not shown). Daily consumption of ash and ether extract was greater $(P<0.01)$ for added CCDS diets compared with control, as a direct consequence of adding the distillers coproduct to the diets. Intakes of total fatty acids and of the major feed fatty acids of C16:0 to C18:3 were greater $(P<0.01)$ for CCDS diets than for the control diet.

\section{Lactational Responses}

Milk production increased $(P<0.01)$ when fed CCDS, but there was no advantage of feeding the higher instead of lower amounts of CCDS (Table 4). This finding agreed with Huhtanen and Miettinen (1992), who observed increased production when cows were fed 5.9\% of their feed DM as wet distillers solubles, but no addi- tional production when fed up to $17.5 \%$ of the ration DM as solubles. Increased production because of addedfat diets have been observed in several studies (Palmquist and Jenkins, 1980; Schingoethe and Casper, 1991). Fat contained in the CCDS diets was likely a contributing factor for greater production from cows fed the CCDS diets and likely contributed to the increased milk production that often occurs when cows are fed distillers grains with solubles (Schingoethe, 2004). Decreased milk fat percentages $(P=0.02)$ coupled with increased $(P<0.01)$ protein and lactose yields were observed for CCDS diets. When comparing both CCDS levels for these milk components, no additional benefit or disadvantage was found for the high CCDS diet. Nevertheless, the same comparison revealed a decrease in lactose percent $(P<0.01)$ for the high vs. low CCDS treatment, a numerically small difference that may not be biologically significant. Greater protein and lactose production for the cows fed CCDS diets corresponded with a greater total milk yield and a similar percentage of components.

Production of $4 \%$ FCM was not affected by treatments because a greater amount of milk that contained a lower percentage of fat was obtained by feeding CCDS. Energy-corrected milk tended to be higher $(P=0.06)$ from cows fed CCDS. Measurements of gross efficiency of production as illustrated by energy-corrected milk per kilogram of DMI (Table 4) showed no difference among diets. This indicates that the nutrients in the different diets supported milk and components production similarly. The tendency $(P=0.12)$ toward greater efficiency for the high vs. the low amount of CCDS simply reflects 
Table 4. Dry matter intake milk yield, milk composition, BW, and BCS for cows fed control (C), low condensed corn distillers solubles (CCDS), and high CCDS diets.

\begin{tabular}{|c|c|c|c|c|c|c|}
\hline \multirow[b]{2}{*}{ Item } & \multicolumn{3}{|c|}{ Diet } & \multirow[b]{2}{*}{$\mathrm{SE}$} & \multicolumn{2}{|c|}{ Contrast $^{1}(P$-value $)$} \\
\hline & Control & Low & High & & 1 & 2 \\
\hline DMI, kg/d & 23.4 & 24.4 & 22.5 & 0.70 & 0.91 & 0.08 \\
\hline Milk, kg/d & 34.1 & 35.5 & 35.8 & 0.39 & $<0.01$ & 0.65 \\
\hline $4 \% \mathrm{FCM}, \mathrm{kg} / \mathrm{d}$ & 32.1 & 32.4 & 33.2 & 0.40 & 0.15 & 0.22 \\
\hline $\mathrm{ECM},{ }^{2} \mathrm{~kg} / \mathrm{d}$ & 34.3 & 35.0 & 35.6 & 0.42 & 0.06 & 0.34 \\
\hline \multicolumn{7}{|l|}{ Fat } \\
\hline$\%$ & 3.54 & 3.33 & 3.43 & 0.05 & 0.02 & 0.22 \\
\hline $\mathrm{kg} / \mathrm{d}$ & 1.22 & 1.21 & 1.25 & 0.02 & 0.88 & 0.18 \\
\hline \multicolumn{7}{|l|}{$\mathrm{CP}$} \\
\hline$\%$ & 2.93 & 2.97 & 2.95 & 0.02 & 0.16 & 0.37 \\
\hline $\mathrm{kg} / \mathrm{d}$ & 1.00 & 1.07 & 1.06 & 0.01 & $<0.01$ & 0.81 \\
\hline \multicolumn{7}{|l|}{ Lactose } \\
\hline$\%$ & 4.97 & 4.99 & 4.92 & 0.02 & 0.38 & $<0.01$ \\
\hline $\mathrm{kg} / \mathrm{d}$ & 1.70 & 1.79 & 1.77 & 0.02 & $<0.01$ & 0.49 \\
\hline $\mathrm{SCC}, \times 10^{3} / \mathrm{mL}$ & 51.7 & 75.9 & 93.1 & 13.7 & 0.07 & 0.39 \\
\hline ECM, kg/kg of DMI & 1.50 & 1.42 & 1.61 & 0.08 & 0.90 & 0.12 \\
\hline $\mathrm{BW}, \mathrm{kg}$ & 586 & 587 & 588 & 7.53 & 0.41 & 0.74 \\
\hline $\mathrm{BCS}^{3}$ & 2.53 & 2.57 & 2.50 & 0.04 & 0.76 & 0.13 \\
\hline
\end{tabular}

${ }^{1}$ Contrast 1 is Control vs. Low and High; contrast 2 is Low vs. High.

${ }^{2} \mathrm{ECM}$ = Energy-corrected milk (Orth, 1992).

${ }^{3}$ Scored on a 5 -point scale where $1=$ emaciated to 5 = overly fat (Wildman et al., 1982).

similar production on the 2 diets but lower DMI $(P=$ 0.08) of the high CCDS diet.

Diets affected the fatty acid composition of milk fat (Table 5). Concentrations of stearic acid (C18:0) and oleic acid $(\mathrm{C} 18: 1)$ were increased $(P<0.01)$ by feeding CCDS diets when compared with control, and further increased ( $P=0.02$ and $P<0.01$, respectively) by the high CCDS diet when contrasted with the low CCDS diet. Short-chain and saturated fatty acid concentrations were not affected by treatment. Medium-chain fatty acids were decreased $(P<0.01)$ and long-chain fatty acids were increased $(P<0.01)$ by added CCDS diets. High CCDS further enhanced these changes in these 2 groups of fatty acids by the same magnitude of probability when compared with low CCDS. Unsaturated fatty acid concentrations in milk fat tended to be higher $(P=0.09)$ for CCDS diets contrasted against control, and were greater $(P<0.01)$ for high compared with low CCDS. Unfortunately, the column conditions used in the GLC for fatty acid analyses in this experiment were not sufficiently sensitive to quantitate amounts of various cis and trans isomers of the 18carbon fatty acids.

Several studies (Palmquist and Jenkins, 1980; Elliott et al., 1993; AbuGhazaleh et al., 2003) have demonstrated that milk fatty acid composition can be altered by feeding because 40 to $45 \%$ of milk fatty acids are passed unchanged, other than by ruminal metabolism, from the diet to milk fat. Adding feedstuffs rich in longchain unsaturated fatty acids to diets has been shown to increase these fatty acids in milk (Grummer, 1991; Palmquist et al., 1993). In the present study, such responses were found to be greater for the high CCDS treatment, which reflected the greater amount of dietary fat that was fed. Studies such as AbuGhazaleh et al. (2003) and Elliott et al. (1993) that observed greater changes in the fatty acid profile of milk fat than we observed used diets with higher total fatty acid concentrations than were used in this study.

\section{Rumen Fluid and Blood}

Table 6 shows ruminal and blood responses to dietary treatments. Acetate concentration was less $(P<0.01)$ for added CCDS compared with control and tended to decrease $(P=0.06)$ for the high vs. the low CCDS diet. Butyrate concentration was augmented, whereas that of isovalerate was diminished for CCDS treatments. Total VFA concentrations tended $(P=0.07)$ to be less for the CCDS diets. Acetate to propionate ratios and rumen fluid $\mathrm{pH}$ were similarly affected by diet. The $\mathrm{pH}$ of rumen fluid was measured immediately at the farm and later in the laboratory to determine if this would affect $\mathrm{pH}$ values; however, $\mathrm{pH}$ values were the same at both times. Ham et al. (1994) observed that feeding CCDS to growing and finishing steers decreased ruminal $\mathrm{pH}$ and tended to decrease acetate to propionate ratios. Rumen fluid ammonia and serum urea values decreased $(P=0.02$ and $P<0.01$, respectively) when cows were fed diets containing CCDS. When comparing 
Table 5. Fatty acid composition of milk fat for cows fed control, low condensed corn distillers solubles (CCDS), or high CCDS diets. ${ }^{1}$

\begin{tabular}{|c|c|c|c|c|c|c|}
\hline \multirow[b]{2}{*}{ Fatty acid ${ }^{3}$} & \multicolumn{3}{|c|}{ Diet } & \multirow[b]{2}{*}{$\mathrm{SE}$} & \multicolumn{2}{|c|}{ Contrast $^{2}(P$-value $)$} \\
\hline & Control & Low & High & & 1 & 2 \\
\hline & $\longrightarrow$ & of fatt & 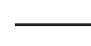 & & & \\
\hline $4: 0$ & 5.9 & 6.3 & 6.4 & 0.20 & 0.06 & 0.73 \\
\hline $6: 0$ & 3.9 & 4.0 & 3.9 & 0.12 & 0.56 & 0.62 \\
\hline $8: 0$ & 2.1 & 2.3 & 2.1 & 0.06 & 0.49 & 0.04 \\
\hline $10: 0$ & 4.3 & 4.4 & 3.9 & 0.11 & 0.36 & 0.01 \\
\hline $12: 0$ & 4.5 & 4.4 & 3.9 & 0.09 & 0.01 & $<0.01$ \\
\hline $14: 0$ & 11.2 & 11.0 & 10.4 & 0.18 & 0.02 & 0.04 \\
\hline $14: 1$ & 1.7 & 1.7 & 1.5 & 0.04 & 0.08 & $<0.01$ \\
\hline $15: 0$ & 1.3 & 1.3 & 1.1 & 0.04 & 0.01 & $<0.01$ \\
\hline $15: 1$ & 0.3 & 0.3 & 0.3 & 0.03 & 0.76 & 0.92 \\
\hline $16: 0$ & 21.8 & 20.5 & 19.8 & 0.34 & $<0.01$ & 0.18 \\
\hline $16: 1$ & 3.0 & 2.7 & 2.7 & 0.10 & $<0.01$ & 0.87 \\
\hline $17: 0$ & 0.8 & 0.7 & 0.7 & 0.04 & 0.03 & 0.41 \\
\hline $17: 1$ & 0.4 & 0.3 & 0.3 & 0.02 & 0.02 & 0.87 \\
\hline $18: 0$ & 10.4 & 10.8 & 11.4 & 0.16 & $<0.01$ & 0.02 \\
\hline $18: 1$ & 20.3 & 20.6 & 23.2 & 0.37 & $<0.01$ & $<0.01$ \\
\hline $18: 2$ & 3.3 & 3.4 & 3.3 & 0.12 & 0.87 & 0.52 \\
\hline Other & 6.4 & 7.0 & 6.5 & 0.28 & 0.28 & 0.28 \\
\hline SCFA $^{4}$ & 20.7 & 21.4 & 20.3 & 0.48 & 0.75 & 0.12 \\
\hline $\mathrm{MCFA}^{5}$ & 40.6 & 38.5 & 36.9 & 0.37 & $<0.01$ & $<0.01$ \\
\hline $\mathrm{LCFA}^{6}$ & 34.0 & 34.8 & 37.9 & 0.53 & $<0.01$ & $<0.01$ \\
\hline Saturated & 64.1 & 63.7 & 61.9 & 0.73 & 0.16 & 0.11 \\
\hline Unsaturated & 29.1 & 29.0 & 31.5 & 0.55 & 0.09 & $<0.01$ \\
\hline
\end{tabular}

${ }^{1}$ Least square means.

${ }^{2}$ Contrast 1 is Control vs. Low and High; contrast 2 is Low vs. High.

${ }^{3}$ Expressed as number of carbons: number of double bonds.

${ }^{4} \mathrm{SCFA}=$ Short-chain fatty acids (4:0 to $12: 0$ ).

${ }^{5} \mathrm{MCFA}=$ Medium-chain fatty acids (14:0 to $17: 1$ ).

${ }^{6} \mathrm{LCFA}=$ Long-chain fatty acids (18:0 to $\left.18: 2\right)$.

different levels of CCDS for such measurements, no difference was observed.

A lower concentration of acetate in ruminal contents of cows fed the CCDS diets may have occurred because of some inhibition of fiber digestion caused by the higher concentrations of long-chain unsaturated fatty acids in those diets (Palmquist and Jenkins, 1980). This may partially explain the decreased milk fat percentage observed when cows were fed CCDS. The tendency $(P=$ $0.07)$ toward lower total VFA concentrations may be partially because of decreased acetate production, but may also be due to less rapidly fermentable carbohydrates in the CCDS diets, because most of the rapidly fermentable carbohydrates such as corn starch were

Table 6. Ruminal volatile fatty acids, $\mathrm{pH}$, and ammonia and serum urea concentrations for cows fed control, low condensed corn distillers solubles (CCDS), or high CCDS diets.

\begin{tabular}{lrrrrrrr}
\hline & \multicolumn{3}{c}{ Diet } & & & \multicolumn{2}{c}{ Contrast $^{1}(P$-value $)$} \\
\cline { 2 - 3 } Measurement & Control & Low & High & SE & 1 & 2 \\
\hline VFA, $\mu$ mol/mL & & & & & & \\
Acetate (A) & 64.4 & 62.1 & 59.6 & 0.87 & $<0.01$ & 0.06 \\
Propionate (P) & 21.9 & 21.7 & 20.9 & 0.55 & 0.37 & 0.32 \\
Isobutyrate & 1.2 & 1.2 & 1.1 & 0.03 & 0.04 & 0.51 \\
Butyrate & 12.4 & 13.1 & 13.4 & 0.21 & $<0.01$ & 0.24 \\
Isovalerate & 2.0 & 1.9 & 1.9 & 0.05 & $<0.01$ & 0.97 \\
Valerate & 1.9 & 2.0 & 2.0 & 0.05 & 0.18 & 0.92 \\
Total & 104.0 & 101.9 & 99.0 & 1.49 & 0.07 & 0.18 \\
A:P ratio & 3.0 & 2.9 & 2.9 & 0.06 & 0.23 & 0.99 \\
pH & 6.5 & 6.5 & 6.6 & 0.05 & 0.52 & 0.27 \\
Ammonia, mg/dL & 19.7 & 18.4 & 17.0 & 0.65 & 0.02 & 0.15 \\
Serum urea, mg/dL & 21.1 & 19.6 & 19.5 & 0.42 & $<0.01$ & 0.85 \\
\hline
\end{tabular}

${ }^{1}$ Contrast 1 is Control vs. Low and High; contrast 2 is Low vs. High. 
removed during the production of distillers products. Decreases in ruminal ammonia and serum urea nitrogen concentrations may indicate less ruminally degradable protein in the added CCDS diets. The high concentrations observed on all diets for these measurements are consistent with the relatively high levels of CP in the diets fed to cows in this study.

\section{CONCLUSIONS}

Results from this study indicate that feeding a diet containing CCDS can increase milk, protein, and lactose production. A slight decrease in milk fat percentage occurred; however, this effect was offset by greater milk production such that there was no change in fat production. Milk fat from cows fed CCDS contained greater proportions of long-chain unsaturated fatty acids, especially when the diet contained 10\% CCDS. Condensed corn distillers solubles fed at $5.0 \%$ of ration DM may be the appropriate amount to feed because no additional benefit, except for greater changes in milk fat composition, was observed when the amount of CCDS fed was doubled. Condensed corn distillers solubles may be an economical source of energy and protein for lactating dairy cattle.

\section{ACKNOWLEDGMENTS}

The authors are grateful to Heartland Grain Fuels, L.P. (Aberdeen, SD) for providing the CCDS utilized in this study and to the South Dakota Corn Utilization Council for partial funding. Appreciation is also extended to Valley Queen Cheese Factory (Milbank, SD) for analyses of milk samples and to the farm crew at the South Dakota State University Dairy Research Facility for care of the cows and assistance with data collection.

\section{REFERENCES}

AbuGhazaleh, A. A., D. J. Schingoethe, A. R. Hippen, and K. F. Kalscheur. 2003. Milk conjugated linoleic acid response to fish oil supplementation of diets differing in fatty acid profiles. J. Dairy Sci. 86:944-953.

AOAC. 1990. Official Methods of Analysis. 15th ed. Association of Official Analytical Chemists, Arlington, VA.

Casper, D. P., D. J. Schingoethe, C. M. J. Yang, and C. R. Mueller. 1987. Protected methionine supplementation with extruded blend of soybeans and soybean meal for dairy cows. J. Dairy Sci. 70:321-330.
Chaney, A. L., and E. P. Marbach. 1962. Modified reagents for determination of urea and ammonia. Clin. Chem. 8:130-132.

Elliott, J. P., J. K. Drackley, D. J. Schauff, and E. H. Jaster. 1993. Diets containing high oil corn and tallow for dairy cows during early lactation. J. Dairy Sci. 76:775-789.

Grummer, R. R. 1991. Effect of feed on the composition of milk fat. J. Dairy Sci. 74:3244-3257.

Ham, G. A., R. A. Stock, T. J. Klopfenstein, E. M. Larson, D. H. Shain, and R. P. Hoffman. 1994. Wet corn distillers byproducts compared with dried corn distillers grains with solubles as a source of protein and energy for ruminants. J. Anim. Sci. 72:3246-3257.

Huhtanen, P., and H. Miettinen. 1992. Milk production and concentrations of blood metabolites as influenced by the level of wet distiller's solubles in dairy cows receiving grass silage-based diet. Agric. Sci. Fin. 1:279-290.

Larson, E. M., R. A. Stock, T. J. Klopfenstein, M. H. Sindt, and R. P. Huffman. 1993. Feeding value of wet distillers byproducts for finishing ruminants. J. Anim. Sci. 71:2228-2236.

National Research Council. 1989. Nutrient Requirements of Dairy Cattle. 6th rev. ed. Natl. Acad. Sci., Washington, DC.

Orth, R. 1992. Sample day and lactation report, DHIA 200. Fact Sheet A-2, Midstates DRPC, Ames, IA.

Ottenstein, D. M., and D. A. Bartley. 1971. Separation of free acids C2-C5 in dilute aqueous solution column technology. J. Chromatogr. Sci. 9:673-681.

Palmquist, D. L., A. D. Beaulieu, and D. M. Barbano. 1993. Feed and animal factors influencing milk fat composition. J. Dairy Sci. 76:1753-1771.

Palmquist, D. L., and T. C. Jenkins. 1980. Fat in lactation rations: Review. J. Dairy Sci. 63:1-14.

Robertson, J. B., and P. J. Van Soest. 1981. The detergent system of analysis and its application to human foods. Page 123-158 in The Analysis of Dietary Fiber. W. P. T. James and O. Theander, ed. Marcel Dekker, New York, NY.

Rust, S. R., J. R. Newbold, and K. W. Metz. 1990. Evaluation of condensed distillers' solubles as an energy source for finishing cattle. J. Anim. Sci. 68:186-192.

SAS Institute. 1989. SAS User's Guide: Statistics. Version 6.08 ed. SAS Inst., Inc., Cary, NC.

Schingoethe, D. J. 2004. Corn coproducts for cattle. Pages 39-47 in Proc. 40th Eastern Nutr. Conf., Ottawa, ON, Canada. Animal Nutrition Association of Canada.

Schingoethe, D. J., M. J. Brouk, and C. P. Birkelo. 1999. Milk production and composition from cows fed wet corn distillers grains. J. Dairy Sci. 82:574-580.

Schingoethe, D. J., and D. P. Casper. 1991. Total lactational response to added fat during early lactation. J. Dairy Sci. 74:2617-2622.

Sukhija, P. S., and D. L. Palmquist. 1988. Rapid method for determination of total fatty acid content and composition of feedstuffs and feces. J. Agric. Food Chem. 36:1202-1206.

Udedibie, A. B. I., and L. E. Chase. 1988. The value of corn condensed distillers solubles (CCDS) for milk production in dairy cows. Niger. Agric. J. 23:118-129.

Van Soest, P. J., J. B. Robertson, and B. A. Lewis. 1991. Methods for dietary fiber, neutral detergent fiber and cornstarch polysaccharides in relation to animal nutrition. J. Dairy Sci. 74:35833597.

Wildman, E. E., G. M. Jones, P. E. Wagner, R. L. Bowman, H. F. Trout, and T. N. Lesch. 1982. Dairy cow body condition scoring and its relationship to selected production characteristics. J. Dairy Sci. 65:495-501. 